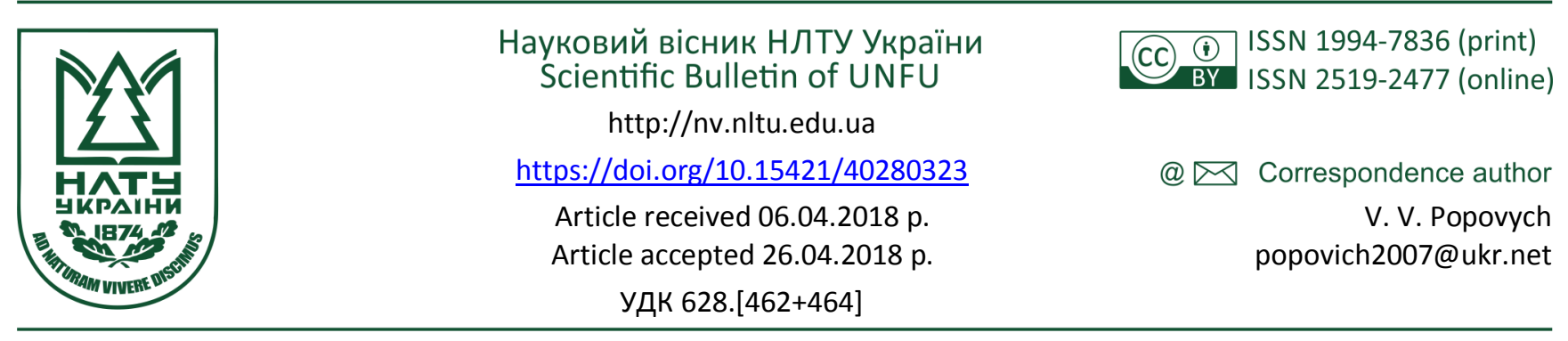

Н. П. Попович1, М. С. Мальований², В. В. Попович³

${ }^{1}$ Львівський держсавний університет внутрішніх справ, м. Львів, Украӥна

${ }^{2}$ Національний університет "Львівська політехніка", м. Львів, Украӥна

${ }^{3}$ Львівський державний університет безпеки життедіяльності, м. Львів, Україна

\title{
ЕФЕКТИВНІСТЬ ЕКСПЛУАТАЦІЇ СПЕЦІАЛЬНОЇ ТЕХНІКИ ДЛЯ ТРАНСПОРТУВАННЯ НЕБЕЗПЕЧНИХ ВІДХОДІВ У СКЛАДІ ПОБУТОВИХ
}

\begin{abstract}
Небезпечні відходи у складі побутових відходів потрібно збирати окремо від інших видів побутових відходів, а також відокремлювати на етапі збирання чи сортування і споживачі та виконавці послуг із вивезення побутових відходів мають їх передавати спеціалізованим підприємствам, що одержали ліцензії на здійснення операцій у сфері поводження з небезпечними відходами. Наведено результати досліджень ефективності експлуатації спеціальної техніки для транспортування небезпечних відходів у складі побутових. Питання ефективності експлуатації спеціальної техніки для транспортування небезпечних відходів у складі побутових $є$ надзвичайно актуальними, тому їх досліджують багато науковців. Проте вивчення ефективності експлуатації сучасних транспортних засобів потребують глибших досліджень та розрахунків. Встановлено, що найкращі показники загальної експлуатаційно-технічної характеристики транспортних засобів для перевезення небезпечних вантажів належать: за питомою масою спеціального обладнання спецавтомобіля: КрАЗ К16.2 - 0,4 т; за питомою потужністю двигуна: OT-20(ISUZU NQR 71P) - 30,7 кВт; за коефіцієнтом компактності: OT-20 (ЗІЛ-433360) - 3,04. Найвищою є середньорічна продуктивність для ОТ-20 (ЗІЛ-433360) і становить 96780,2 т км/рік. За вантажопідйомністю (16 т) та об'ємом контейнера для небезпечних відходів у складі твердих побутових $\left(30 \mathrm{~m}^{3}\right)$ найкращі технічні характеристики належать спецавтомобілю КрАЗ К16.2.
\end{abstract}

Ключові слова: екологічна безпека; екологічна небезпека; транспортні засоби; сміттєзвалище.

Вступ. Одним із ключових принципів екологічної безпеки держави є ефективне поводження із відходами. Вагомим чинником впливу на довкілля $є$ наявність небезпечних відходів у складі побутових. Небезпечні відходи у складі побутових відходів - це відходи, що утворюються у процесі життєдіяльності людини в житлових та нежитлових будинках і мають такі фізичні, хімічні, біологічні чи інші небезпечні властивості, які створюють або можуть створити значну небезпеку для довкілля або здоров'я людини та які потребують спеціальних методів і засобів поводження з ними (Postanova, 2008).

Небезпечні відходи у складі побутових відходів потрібно збирати окремо від інших видів побутових відходів, а також відокремлювати на етапі збирання чи сортування і споживачі та виконавці послуг із вивезення побутових відходів мають їх передавати спеціалізованим підприємствам, що одержали ліцензії на здійснення операцій у сфері поводження з небезпечними відходами (Postanova, 2008). Проте в населених пунктах нашої держави спостерігаємо тенденцію щодо накопичення у контейнерах небезпечних відходів разом із побутовими. Така ситуація пов'язана насамперед із тим, що відсутні спеціальні контейнери для небезпечних відходів. Також вагомими чинниками потрапляння небезпечних відходів у контейнери для загального збирання побутових відходів $є$ відсутність спеціальних установок для перероблення та спеціальної техніки для їх транспортування.

Аналіз останніх досліджень та публікацій. Питання щодо транспортування побутових відходів та небезпечних в їх складі розглянуто в багатьох наукових працях як українських, так і зарубіжних вчених. Серед таких праць варто зазначити наукові публікації О. В. Березюка, у яких відображено конструктивні особливості сміттєвозів та пріоритетні напрями вдосконалення конструкцій машин для збирання та первинного перероблення твердих побутових відходів (Bereziuk, 2015a, 2015b). У роботі (Ishchenko, 2016) наведено аналіз поводження 3 небезпечними компонентами побутових відходів у Вінницькій області, який показав відсутність системи поводження з ними.

Наукова робота (Bublyk, 2012) стосується аналізу утворення відходів виробництва за основними групами небезпечних відходів, досліджено обсяги відходів на під-

Інформація про авторів:

Попович Наталія Пилипівна, викладач, кафедра адміністративно-правових дисциплін. Email: vinata7@gmail.com

Мальованый Мирослав Степанович, д-р техн. наук, професор, завідувач кафедри екології та збалансованого природокористування. Email: myroslav.mal@gmail.com; http://orcid.org/0000-0002-3868-1070

Попович Василь Васильович, д-р техн. наук, доцент, начальник кафедри екологічної безпеки. Email: popovich2007@ukr.net; http://orcid.org/0000-0003-2857-0147

Цитування за Дсту: Попович Н. П., Мальований М. С., Попович В. В. Ефективність експлуатації спеціальної техніки для транспортування небезпечних відходів у складі побутових. Науковий вісник НлтУ України. 2018, т. 28, № 3. С. 111-116.

Citation APA: Popovych, N. P., Malovanyy, M. S., \& Popovych, V. V. (2018). Effectiveness of Specialised Equipment Operation for Transportation of Hazardous Waste in the Composition of Household Materials. Scientific Bulletin of UNFU, 28(3), 111-116. https://doi.org/10.15421/40280323 
приємствах Львівської області та динаміку поводження 3 ними. Також наведено відмінності у поглядах щодо поводження з відходами та процесами управління відходами. Автор запропонував систему логістики рециклінгу у складі механізму регулювання техногенних збитків підприємства та схему індустріального симбіозу підприємств із метою зменшення техногенних збитків.

У наукових працях (Popovych et al., 2013, 2014) досліджено транспортні засоби для перевезення небезпечних (радіоактивних) відходів. Наведено дані про транспортні засоби для перевезення небезпечних побутових відходів та вимоги до них. Розроблено логістичну схему перероблення та складування небезпечних відходів. Встановлено, що транспортування небезпечних побутових відходів може відбуватися за централізованою та децентралізованою схемами.

$\mathrm{У}$ роботі (Popovych et al., 2017) встановлено, що на ефективність застосування сміттєвоза впливають такі параметри, як: маса відходів, об'єм відходів, маса транспортного засобу, габаритні розміри транспортного засобу, об'єм кузова. Оцінювання ефективності є складним завданням та потребує окремого розгляду. Ії̈ розглядають за часовими характеристиками доставляння твердих побутових відходів і підготовчо-заключних операцій.

Отже, питання ефективності експлуатації спеціальної техніки для транспортування небезпечних відходів у складі побутових є надзвичайно актуальними, які досліджують багато науковців. Проте вивчення ефективності експлуатації сучасних транспортних засобів потребують глибших досліджень та розрахунків.

Мета та завдання дослідження. Метою роботи $\epsilon$ встановити техніко-експлуатаційні показники спеціальних транспортних засобів, які призначені для перевезення небезпечних речовин, та вибрати найбільш оптимальну модель. Відповідно до мети потрібно виконати такі завдання:

- встановити моделі транспортних засобів, які конструктивно призначені для транспортування небезпечних речовин (небезпечних відходів у складі твердих побутових);

- здійснити розрахунки граничної відстані транспортування небезпечних речовин (небезпечних відходів у складі твердих побутових) та середньорічної продуктивності спеціальної техніки;

- встановити технічний рівень спеціальної техніки для транспортування небезпечних речовин (небезпечних відходів у складі твердих побутових).

Результати дослідження та їх обговорення. На підприємствах нашої держави виготовляють незначну кількість спеціальних транспортних засобів для перевезення небезпечних відходів у складі побутових: КрАЗ K16.2 (АвтоКрА3, м. Кременчук), ОТ-10А ("Тітал", м. Київ), ОТ-20 ("Тітал", м. Київ). Водночас експлуатують на потенційно небезпечних об'єктах ОТ-20 на базі ЗІЛ-433360 та спеціальний автомобіль СА-11 на базі КамА3-6540. Проаналізуємо технічний рівень транспортних засобів для перевезення небезпечних відходів у складі твердих побутових із метою встановлення найбільш прийнятного для експлуатації.

Спеціальний автомобіль ОТ-10А на шасі КамАЗ43253 із колісною формулою $4 \times 2$ має сталевий кузовконтейнер. Маніпулятора в автомобіля немає (рис. 1, табл. 1). Спеціальний автомобіль ОT-20 на шасі ISUZU NQR 71P із колісною формулою $4 \times 2$ має кран-маніпулятор (рис. 2, табл. 2).
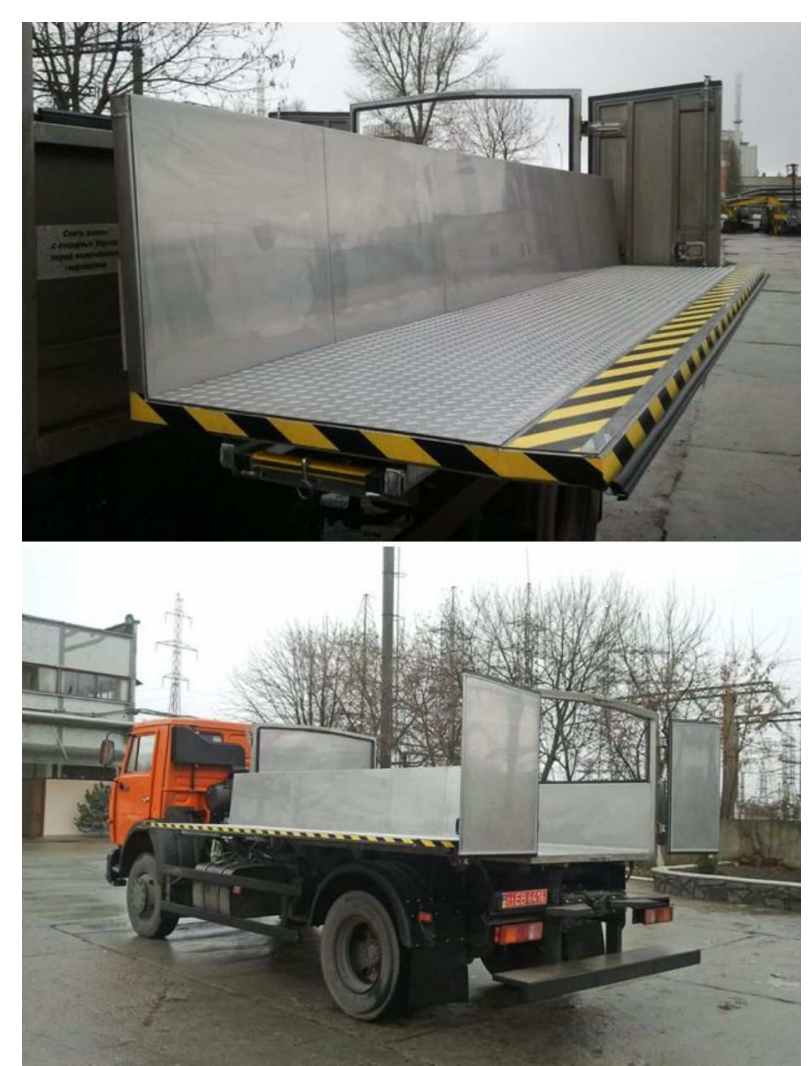

Рис. 1. Загальний вигляд ОТ-10А (фото запозичено з офіційного сайту компанії "Тітал")

Табл. 1. Технічні характеристики ОТ-10А (КамА3-43253, 4×2)

\begin{tabular}{|l|c|}
\hline \multicolumn{1}{|c|}{ Особовий склад, осіб } & $1+1$ \\
\hline Вантажопідйомність, кг & 5000 \\
\hline Спеціальний кузов-контейнер & \\
\hline - матеріал & сталь \\
\hline - об’єм, м & 7,7 \\
\hline - захисний екран, товщина, мм & свинцева пластина, 30 \\
\hline
\end{tabular}
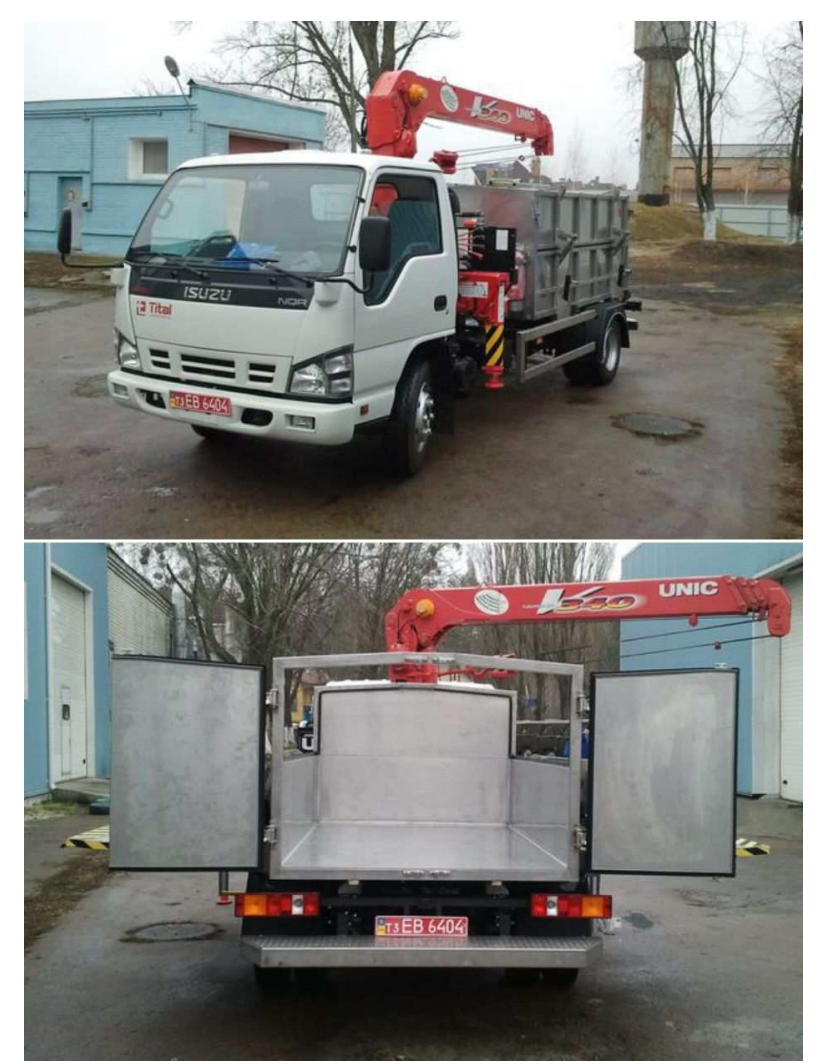

Рис. 2. Загальний вигляд ОТ-20 (фото запозичено з офіційного сайту компанії "Тітал") 
Табл. 2. Технічні характеристики ОT-20 (ISUZU NQR 71P, 4×2)

\begin{tabular}{|l|c|}
\hline \multicolumn{1}{|c|}{ Особовий склад, осіб } & $1+1$ \\
\hline Вантажопідйомність, кг & 2900 \\
\hline Об'єм кузова, м & 5,1 \\
\hline Кран-маніпулятор & UNIC UR-V344 \\
\hline $\begin{array}{l}\text { Вантажопідйомність крана-маніпуля- } \\
\text { тора, т/м }\end{array}$ & $3 / 2,6$ \\
\hline Робочий радіус, м & $0,67 \ldots 9,81$ \\
\hline Макс. виліт стріли, м & 10 \\
\hline Захисний екран, товщина, мм & свинцева пластина, 15 \\
\hline
\end{tabular}
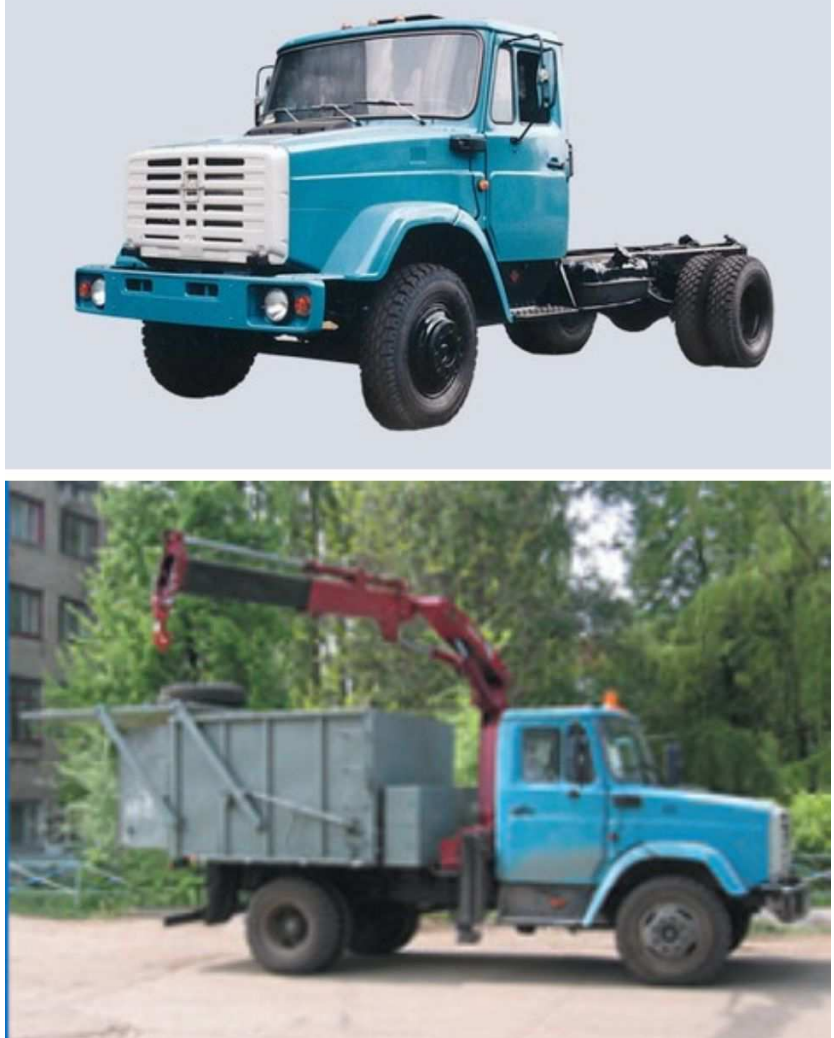

Рис. 3. Загальний вигляд ОТ-20 (ЗІЛ-433360) (фото запозичено з відкритих джерел мережі Internet)

Машину для перевезення твердих радіоактивних відходів ОТ-20 (ЗІЛ-433360) призначено для перевезення твердих і рідких промислових та радіоактивних відходів. Спецкузов виготовлено 3 нержавіючої сталі, об'ємом 5,29; 6,44; 6, 73 м³. Для захисту водія від опромінення встановлено захисний свинцевий екран товщиною 30 мм. Маніпуляторною установкою скомплектовано кран різної вантажопідйомності виробництва різних країн. Спецкузов обладнано знімними касетами для перевезення контейнерів із твердими радіоактивними відходами (рис. 3, табл. 3).

Табл. 3. Технічні характеристики ОТ-20 (ЗІЛ-433360)

\begin{tabular}{|l|c|}
\hline \multicolumn{1}{|c|}{ Базове шасі } & Забаритні розміри, мм: \\
\hline \multicolumn{2}{|c|}{ Газ33360 } \\
\hline довжина & 6430 \\
\hline ширина & 2500 \\
\hline висота & 3220 \\
\hline Маса спорядженої машини, кг & 7250 \\
\hline Повна маса, кг & 11200 \\
\hline Маса перевізного вантажу, кг & 3700 \\
\hline
\end{tabular}

Автомобіль для перевезення радіоактивних матеріалів СА-11 (КамАЗ-6540) призначено для транспортування радіоактивних речовин у контейнерах на теритоpiї об'єкта ядерного паливного циклу, із забезпеченням їх кріплення і захисту від атмосферних опадів, 3 дотриманням правил і норм безпеки.

Конструктивні особливості спеціального автомобіля CA-11:

- шумоізоляція кузова;

- хімічно стійкі лакофарбові покриття;

- захист контейнерів від атмосферних опадів;

- рама надбудови зі сталі підвищеної міцності;

- радіаційний захист кабіни з конструкційної сталі;

- захист від вивітрювання радіоактивних аерозолів з кузова;

- розсувний 2-секційний кузов зі сталі, стійкої до корозії;

- можливість проведення дезактивації кузова миючими розчинами;

- система кріплення контейнерів упорами і притисками з ланцюговими стяжками;

- можливість збирання і відводу дезактивних розчинів у спеціальну каналізацію;

- кузов обладнано дверима, трапом і огорожами для дотримання техніки безпеки (рис. 4, табл. 4).

Табл. 4. Технічні характеристики СА-11

\begin{tabular}{|c|c|}
\hline Шасі & КамАЗ-6540 \\
\hline Колісна формула & $8 \times 4$ \\
\hline Тип двигуна & дизельний, з турбонаддувом \\
\hline Потужність двигуна, кВт (л.с.) & $206(280)$ \\
\hline Паливний бак, л & 210 \\
\hline Коробка передач & механічна, 5-ступенева \\
\hline Гальма & барабанні \\
\hline Споряджена маса, кг & 16700 \\
\hline Повна маса, кг & 26700 \\
\hline Вантажопідйомність, кг & 10000 \\
\hline Габаритні розміри, мм & $8150 \times 2790 \times 3600$ \\
\hline $\begin{array}{l}\text { Tранспортна швидкість, } \\
\text { км/год }\end{array}$ & $\mathrm{c}_{\mathrm{r}} \mathrm{r}_{\mathrm{c}}$ \\
\hline Зовнішній радіус повороту, м & 10,5 \\
\hline
\end{tabular}
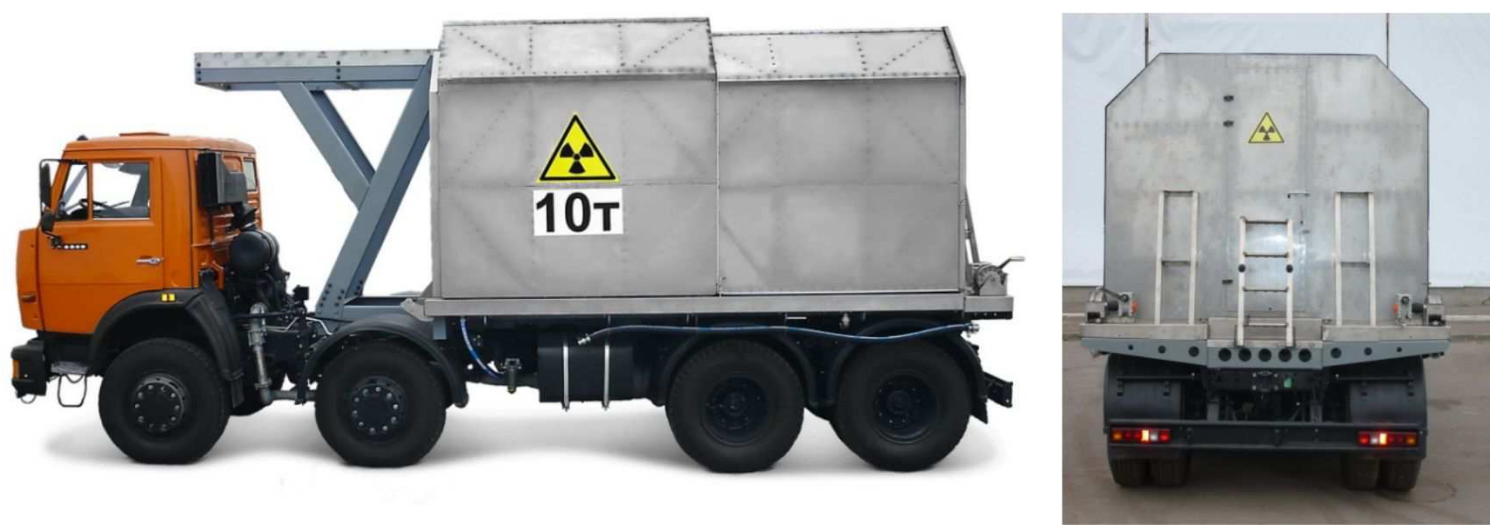

Рис. 4. Загальний вигляд СА-11 (фото запозичено з відкритих джерел мережі Internet) 
Автомобіль КрАЗ К16.2 призначено для механізованого завантаження, транспортування і вивантаження в місцях утилізації твердих побутових, великогабаритних будівельних і промислових відходів, а також для транспортування змінних кузовів різного функціонального призначення. Його обладнано самоскидальним металевим контейнером з відкривним заднім бортом, краномманіпулятором зі змінними спеціальними захватами i вантажно-розвантажувальним механізмом (мультиліфтом).

Мультіліфтова система крюкового типу з гідравлічним приводом забезпечує швидке завантаження і зняття змінного кузова і дає змогу перевозити кузови різного призначення. Для механізованого навантаження твердих побутових відходів із депо-контейнерів різної ємності використовують контейнерний захват, а для навантаження великогабаритних будівельних і промислових відходів - грейферний або гаковий захвати. Вивантаження вантажу здійснюється самоскидальним способом під час підйому кузова (Herelytsia \& Herelytsia, 2010; Velikanov, 1969). Автомобільне шасі КрАЗ Н23.2 має високу маневреність, що дає змогу ефективно працювати в обмежених умовах вулично-дорожньої мережі (рис. 5).
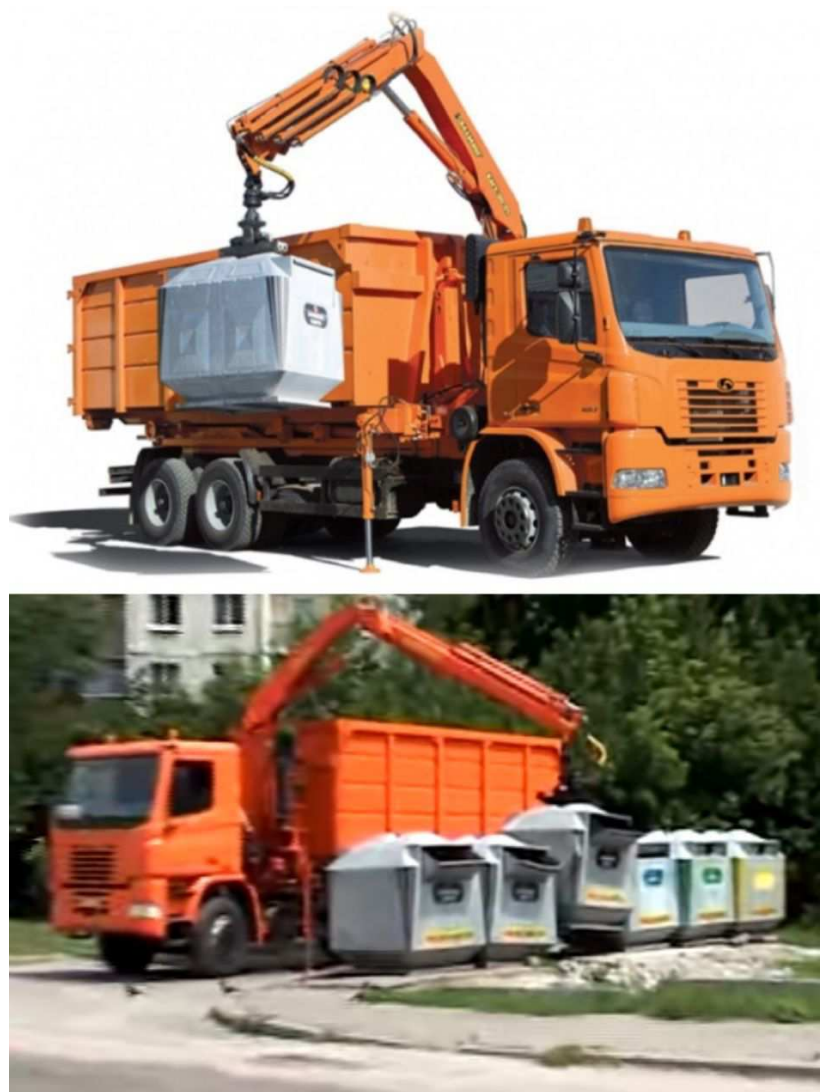

Рис. 5. Загальний вигляд КрАЗ К16.2 (фото запозичено з відкритих джерел мережі Internet та офіційного сайту компанії "Авто КрАЗ")
Розрахунок граничної відстані транспортування небезпечних відходів у складі твердих побутових та середньорічної продуктивності спеціальної техніки. Згідно з (Bereziuk, 2015b), умовою вибору транспортного засобу, для конкретних умов роботи, з погляду максимального виробітку, є величина граничної відстані перевезення, за якої використання одного транспортного засобу стає доцільнішим, порівняно 3 іншим. Граничну відстань транспортування під час порівняння двох транспортних засобів визначають як

$$
L=\frac{q_{H}^{1} \gamma^{1} t^{2}-q_{H}^{2} \gamma^{2} t^{1}}{\frac{q_{H}^{2} \gamma^{2}}{\beta v^{1}}-\frac{q_{H}^{1} \gamma^{1}}{\beta v^{2}}}=\frac{q_{H}^{1} \gamma^{1} t^{2}-q_{H}^{2} \gamma^{2} t^{1}}{q_{H}^{2} \gamma^{2} v^{2}-q_{H}^{1} \gamma^{1} v^{1}} \beta v^{1} v^{2}
$$

де: $q_{t}-$ номінальна вантажопідйомність транспортного засобу, т; $\gamma$ - коефіцієнти використання вантажопідйомності; $t$ - час завантаження та розвантаження автомобіля, год; $\beta$ - коефіцієнт використання пробігу; $v$ - швидкість руху транспортних засобів, км/год.

Існують загальноприйняті методи розрахунку продуктивності вантажного автомобіля чи автопоїзда (Bereziuk, 2015a). У нашому випадку для порівняльної оцінки ефективності використання різних конструкцій доцільно визначати продуктивність середню за рік для виключення впливу сезонних та добових коливань. Середньорічну продуктивність вантажного автомобіля чи автопоїзда визначають за формулою (т км/рік)

$$
W_{p}=\frac{q \gamma l \beta v_{m} T 365 \alpha}{l+\beta v_{m} t_{b-p}},
$$

де: $q_{H}-$ номінальна вантажопідйомність транспортного засобу, т; $\gamma$ - коефіцієнт використання вантажопідйомності; $t_{6-p}-$ час завантаження та розвантаження автомобіля, год; $\beta$ - коефіцієнт використання пробігу; $v_{m}-$ технічна швидкість руху транспортного засобу, км/год; $\alpha-$ коефіцієнт використання автомобіля; $l$ - середня довжина їздки із вантажем, км; $T$ - час у наряді, год.

Варто зазначити, що деякі техніко-експлуатаційні показники для спеціальних транспортних засобів ОT10A (КамА3-43253) і OT-20 (ISUZU NQR 71P) вже розглянуто в науковій статті (Рopovych et al., 2014), проте вони потребують доповнення та порівняння з іншим рухомим складом.

Вихідні дані для проведення розрахунків наведено у табл. 5.

Отже, після проведення розрахунків за залежністю (2) встановлено середньорічну продуктивність спеціальних машин для перевезення небезпечних відходів у складі побутових (табл. 6).

За результатами проведених розрахунків встановлено, що найвищою $є$ середньорічна продуктивність для ОТ-20 (ЗІЛ-433360), що становить 96780,2 т км/рік. Показник середньорічної продуктивності спеціального автомобіля має важливе значення під час транспортування небезпечних відходів у складі твердих побутових у межах міста. У табл. 7 наведено матрицю розрахунку дальності транспортування.

Табл. 5. Вихідні дані для розрахунку граничної відстані транспортування та середньорічної продуктивності

\begin{tabular}{|c|c|c|c|c|c|c|c|c|c|}
\hline Тип спецтранспорту & Шасі & $q_{H}, \mathrm{~T}$ & $v$, км/год & $\gamma$ & $\beta$ & $t$, год & $l, \mathrm{KM}$ & $\alpha$ & $T$, год \\
\hline OT-10A & КамА3-43253 & 5 & 90 & 0,75 & 0,55 & 1 & 15 & 0,7 & 8 \\
\hline OT-20 & ISUZU NQR 71P & 2,9 & 120 & 0,7 & 0,52 & 0,5 & 15 & 0,7 & 8 \\
\hline OT-20 & 3ІЛ-433360 & 3,7 & 90 & 0,7 & 0,52 & 0,5 & 15 & 0,7 & 8 \\
\hline CA-11 & КамАЗ-6540 & 10 & 80 & 0,5 & 0,5 & 1,5 & 15 & 0,7 & 8 \\
\hline KpA3 K16.2 & KрA3 H23.2 & 16 & 85 & 0,7 & 0,5 & 0,5 & 15 & 0,7 & 8 \\
\hline
\end{tabular}
транспортних засобів 
Табл. 6. Встановлена середньорічна продуктивність досліджуваних транспортних засобів

\begin{tabular}{|c|c|c|}
\hline Тип спецтранспорту & Шасі & $W$, т км/piк \\
\hline OT-10A & KaмA3-43253 & 71588,2 \\
\hline OT-20 & ISUZU NQR 71P & 94064,1 \\
\hline OT-20 & 3IЛ-433360 & 96780,2 \\
\hline CA-11 & КамA3-6540 & 81760,0 \\
\hline KрА3 К16.2 & КрА3 H23.2 & 25162,3 \\
\hline
\end{tabular}

Табл. 7. Матриця розрахунку дальності транспортування

\begin{tabular}{|c|c|c|c|c|c|}
\hline Тип спецтранспорту & $\begin{array}{c}\text { OT-10A (КамA3- } \\
43253)\end{array}$ & $\begin{array}{c}\text { OT-20 (ISUZU } \\
\text { NQR 71P) }\end{array}$ & $\begin{array}{c}\text { OT-20 (3IЛ- } \\
433360)\end{array}$ & $\begin{array}{c}\text { CA-11 (КамA3- } \\
6540)\end{array}$ & КрA3 К16.2(H23.2) \\
\hline OT-10A (КамA3-43253) & $*$ & 7,75 & 23,83 & 0,68 & $-45,4$ \\
\hline OT-20 (ISUZU NQR 71P) & 7,75 & $*$ & 142,5 & 9,73 & $-35,4$ \\
\hline OT-20 (3IЛ-433360) & 23,83 & 142,5 & $*$ & $-0,21$ & $-23,9$ \\
\hline CA-11 (КамA3-6540) & 0,68 & 9,73 & $-0,21$ & $*$ & $-89,4$ \\
\hline КрА3 К16.2(H23.2) & $-45,4$ & $-35,4$ & $-23,9$ & $-89,4$ & $*$ \\
\hline
\end{tabular}

Отже, внаслідок проведених розрахунків встановлено, що найбільша гранична відстань транспортування небезпечних відходів у складі побутових, після порівняння двох транспортних засобів, становить для ОТ-20 (ЗІЛ-433360) - від 23,83 км до 142,5 км.

Технічний рівень спеціальної техніки для транспортування небезпечних відходів у складі твердих побутових. Відомо, що основними показниками, які характеризують технічний рівень транспортних засобів для перевезення небезпечних вантажів, є питома маса спецобладнання (т), питома потужність двигуна (кВт/т), коефіцієнт компактності $\left(\mathrm{M}^{2} / \mathrm{M}^{3}\right)$ (Aleksandrovskaia et al., 1984).

Питому масу спеціального обладнання визначають за залежністю (3)

$$
q_{n}=\frac{q_{o б}}{Q},
$$

де: $q_{\text {об }}$ - маса спеціального обладнання, т; $Q$ - маса небезпечних відходів, які транспортуються, т.
Питому потужність двигуна визначають як відношення потужності двигуна базового автомобіля до маси небезпечних відходів, які транспортують (4):

$$
N_{n}=\frac{N}{Q}
$$

де $N$ - потужність двигуна базового автомобіля, кВт.

Коефіцієнт компактності - це відношення площі, яку займає автомобіль до місткості кузова (5):

$$
\eta=\frac{L_{T 3} \cdot B_{T 3}}{V_{K}}
$$

де: $L_{T 3}-$ довжина транспортного засобу, м; $B_{T 3}$ - ширина транспортного засобу, м; $V_{K}-$ об'єм кузова, м³ .

Вихідні дані для розрахунку технічного рівня транспортних засобів наведено у табл. 8.

Результати розрахунків технічного рівня транспортних засобів для перевезення небезпечних відходів наведено у табл. 9 .

Табл. 8. Вихідні дані для розрахунку технічного рівня транспортних засобів

\begin{tabular}{|c|c|c|c|c|c|c|c|}
\hline Тип спецтранспорту & Шасі & $q_{o \sigma}, \mathrm{T}$ & $Q, \mathrm{~T}$ & $N, \mathrm{\kappa BT}$ & $L_{T 3}, \mathrm{M}$ & $B_{T 3}, \mathrm{M}$ & $V_{K}, \mathrm{M}^{3}$ \\
\hline OT-10A & KaмA3-43253 & 0,5 & 5 & 149,3 & 7,48 & 2,5 & 7,7 \\
\hline OT-20 & ISUZU NQR 71P & 0,6 & 2,9 & 89 & 6,61 & 2,11 & 5,1 \\
\hline OT-20 & 3IЛ-433360 & 0,6 & 6 & 136 & 6,43 & 2,5 & 5,29 \\
\hline CA-11 & KaмA3-6540 & 1 & 10 & 206 & 8,15 & 2,79 & 22,2 \\
\hline KрA3 K16.2 & KpA3 H23.2 & 6,4 & 16 & 266 & 9,2 & 2,49 & 30 \\
\hline
\end{tabular}

Табл. 9. Експлуатаційно-технічна характеристика транспортних засобів для перевезення небезпечних відходів

\begin{tabular}{|c|c|c|c|c|}
\hline Тип спецтранспорту & Шасі & $q_{n}, \mathrm{~T}$ & $N_{n}, \mathrm{\kappa BT} / \mathrm{T}$ & $\eta$ \\
\hline OT-10A & KaмA3-43253 & 0,1 & 29,9 & 2,43 \\
\hline OT-20 & ISUZU NQR 71P & 0,2 & 30,7 & 2,73 \\
\hline OT-20 & 3IЛ-433360 & 0,1 & 22,7 & 3,04 \\
\hline СА-11 & КамA3-6540 & 0,1 & 20,6 & 1,02 \\
\hline KрА3 К16.2 & KрA3 H23.2 & 0,4 & 16,6 & 0,76 \\
\hline
\end{tabular}

Висновки. Спеціальна техніка для транспортування відходів та небезпечних відходів у складі побутових відіграє важливу роль у сфері збереження довкілля та підвищення екологічної безпеки. Питання підвищення ефективності спеціальної техніки для транспортування небезпечних відходів прямо впливають на можливість міграції небезпечних речовин у біоту.

Дослідження показали, що найкращі показники загальної експлуатаційно-технічної характеристики транспортних засобів для перевезення небезпечних вантажів належать: за питомою масою спеціального обладнання спецавтомобіля - КрАЗ К16.2 - 0,4 т; за питомою потужністю двигуна - OT-20 (ISUZU NQR 71P) 30,7 кВт; за коефіцієнтом компактності - ОТ-20 (ЗІЛ$433360)-3,04$. Найвищою $є$ середньорічна продуктивність для ОТ-20 (ЗІЛ-433360), що становить 96780,2 т км/рік.
За вантажопідйомністю (16 т) та об'ємом контейнера для небезпечних відходів у складі твердих побутових $\left(30 \mathrm{~m}^{3}\right)$ найкращі технічні характеристики належать спецавтомобілю КрАЗ К16.2.

\section{Перелік використаних джерел}

Aleksandrovskaia, Z. I., Bukreev, E. M., Medvedev, Ia. V., \& Iuskevich, N. N. (1984). Blagoustroistvo gorodov. Moscow: Stroiizdat. 341 p. [In Russian].

Bereziuk, O. V. (2015a). Ohliad konstruktsii mashyn dlia zbyrannia ta pervynnoho pereroblennia tverdykh pobutovykh vidkhodiv. Visnyk mashynobuduvannia ta transportu, 1, 3-8. [In Ukrainian].

Bereziuk, O. V. (2015b). Struktura mashyn dlia zbyrannia ta pervynnoi pereroblennia tverdykh pobutovykh vidkhodiv. Visnyk mashynobuduvannia ta transportu, 2, 3-7. [In Ukrainian].

Bublyk, M. I. (2012). Mekhanizm rehuliuvannia tekhnohennykh zbytkiv promyslovykh pidpryiemstv: lohistyka retsykliuvannia yak instrument yoho zastosuvannia. Visnyk Natsionalnoho universytetu "Lvivska politekhnika", 749, 530-537. [In Ukrainian]. 
Herelytsia, R. O., \& Herelytsia, N. Ye. (2010). Upravlinnia transportnoiu lohistykoiu $\mathrm{v}$ silskohospodarskykh pidpryiemstvakh. Innovatsiina ekonomika, 292-298. [In Ukrainian].

Ishchenko, V. A. (2016). Povodzhennia z nebezpechnymy komponentamy pobutovykh vidkhodiv u Vinnytskii oblasti. Retrieved from: https://www.researchgate.net/publication/319528404_povodzenna z_nebezpecnimi_komponentami_pobutovih_vidhodiv_u_vinnickij oblasti. [In Ukrainian].

Popovych, V. V., Popovych, N. P., \& Buchkovskyi, A. I. (2013). Lohistychna systema transportuvannia nebezpechnykh vidkhodiv v umovakh mista. Visnyk LDUBZhD, 8, 166-171. [In Ukrainian].

Popovych, V. V., Popovych, N., \& Kravchuk, M. M. (2014). Kryterii vyboru transportnykh zasobiv dlia perevezennia nebezpechnykh

(radioaktyvnykh) vidkhodiv [Selection of the criteria for vehicles for the dangerous (radioactive) waste transportation]. Scientific Bulletin of UNFU, 24(1), 171-177. [In Ukrainian].

Popovych, V. V., Prydatko, O. V., Sychevskyi, M. I., Popovych, N. P., \& Panasiuk, M. A. (2017). The efficiency of garbage trucks operation in the city - landfill environment. Scientific Bulletin of UNFU, 27(10), 73-76. https://doi.org/10.15421/40271012

Postanova. (2008). Postanova Kabinetu Ministriv Ukrainy vid 10.12.2008 r., № 1070 "Pro zatverdzhennia Pravyl nadannia posluh z vyvezennia pobutovykh vidkhodiv". [In Ukrainian].

Velikanov, D. P. (1969). Effektivnostb avtomobilia. Moscow: Transport. 240 p. [In Russian].

Н. Ф. Попович1, М. С. Мальованый², В. В. Попович 3

${ }^{1}$ Львовский государственный университет внутренних дел, г. Львов, Украина

${ }^{2}$ Национальный университет "Львовская политехника", г. Львов, Украина

3 Львовский государственный университет безопасности жизнедеятельности, г. Львов, Украина

\title{
ЭФФЕКТИВНОСТЬ ЭКСПЛУАТАЦИИ СПЕЦИАЛЬНОЙ ТЕХНИКИ ДЛЯ ТРАНСПОРТИРОВКИ ОПАСНЫХ ОТХОДОВ В СОСТАВЕ БЫТОВЫХ
}

\begin{abstract}
Опасные отходы в составе бытовых отходов собираются отдельно от других видов отходов, а также должны отделяться на этапе сбора или сортировки и передаваться потребителями и исполнителями услуг по вывозу бытовых отходов специализированным предприятиям, получившим лицензии на осуществление операций в сфере обращения с опасными отходами. Приведены результаты исследований эффективности эксплуатации специальной техники для транспортировки опасных отходов в составе бытовых. Вопросы эффективности эксплуатации специальной техники для транспортировки опасных отходов в составе бытовых чрезвычайно актуальны и исследуются многими учеными. Однако изучение эффективности эксплуатации современных транспортных средств требует более глубоких исследований и расчетов. Установлено, что наилучшие показатели общей эксплуатационно-технической характеристики транспортных средств для перевозки опасных грузов относятся: по удельной массе специального оборудования к спецавтомобилю: КрАЗ К16.2-0,4 т; по удельной мощности двигателя: OT-20 (ISUZU NQR 71P) - 30,7 кВт; по коэффициенту компактности: ОТ-20 (ЗИЛ-433360) - 3,04. Наивысшей является среднегодовая производительность для ОТ-20 (ЗИЛ-433360) и составляет 96780,2 т км / год. По грузоподъемности (16 т) и объему контейнера для опасных отходов в составе твердых бытовых $\left(30 \mathrm{~m}^{3}\right)$ наилучшие технические характеристики принадлежат спецавтомобилю КрАЗ К16.2.
\end{abstract}

Ключевые слова: экологическая безопасность; экологическая опасность; транспортные средства; свалка.

\author{
N. P. Popovych', M. S. Malovanyy', V. V. Popovych ${ }^{3}$ \\ ${ }^{1}$ Lviv State University of Internal Affairs, Lviv, Ukraine \\ ${ }^{2}$ Lviv Polytechnic National University, Lviv, Ukraine \\ ${ }^{3}$ Lviv State University of Life Safety, Lviv, Ukraine
}

\section{EFFECTIVENESS OF SPECIALISED EQUIPMENT OPERATION FOR TRANSPORTATION OF HAZARDOUS WASTE IN THE COMPOSITION OF HOUSEHOLD MATERIALS}

One of the key principles of state environmental safety is the efficient waste management. A significant factor in the impact on the environment is the presence of hazardous waste in the household materials. There is a tendency to accumulate hazardous waste in containers together with household ones in Ukraine's settlements. Hazardous waste in the composition of household waste is collected separately from other types of household waste; it should be also separated at the stage of collection or sorting and passed by consumers and operators of household waste disposal services to specialized enterprises having licenses for operations in the field of hazardous waste management. This situation is primarily due to the lack of specialized containers for hazardous waste and specialized equipment. Therefore, the purpose of the research is to define technical and operational indicators of specialized vehicles for hazardous substances transportation and to choose the most optimal model. The authors used mathematical and statistical methods in the course of the study. We present the results of investigation of efficiency of operation of the specialized equipment for transportation of hazardous waste in household waste composition. The issue of the efficiency of the operation of specialized equipment for the transportation of hazardous waste in the household waste composition is extremely relevant; hence it is being researched by many scientists. However, the study of the efficiency of modern vehicles operation requires in-depth research and calculations. Consequently, the best indicators of the overall operational and technical characteristics of the vehicles for the transportation of hazardous stuff are as follows: according to the specific weight of specialized vehicle equipment: KRAZ K16.2-0.4 tons; for specific engine power: OT-20 (ISUZU NQR 71P) - $30.7 \mathrm{~kW}$; by the coefficient of compactness: OT-20 (ZIL-433360) - 3.04. The highest annual average productivity for OT-20 (ZIL-433360) is $96780.2 \mathrm{t} \mathrm{km} /$ year. By the load capacity (16 tons) and the volume of the container for hazardous waste in the solid household waste $(30 \mathrm{~m} 3)$, a specialized KRAZ K16.2 has the best technical characteristics.

Keywords: environmental safety; environmental hazard; vehicles; landfill. 